\title{
Koulutus ja työelämä muutoksessa
}

\author{
MARJA-LEENA STENSTRÖM
}

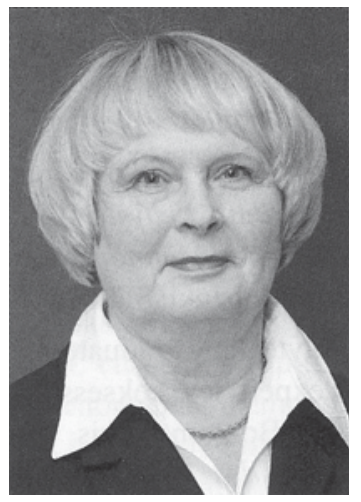

Ammattitaito on koulutuksella ja kokemuksella hankittu pätevyys toimia määrätyssä amatissa. Useat viimeaikaiset tutkimukset osoittavat, että ammattilaiset kokevat oppineensa jopa suurimman osan työssä tarvittavista taidoista vasta työssä. Elinikäinen oppiminen voidaankin nähdä erääksi avainprosessiksi työelämän muutoksen hallinnassa. Erityisesti tämä koskee ikääntyviä työntekijöitä. Vaikka suomalaiset ovat kansainvälisesti aktiiveja aikuisopiskelijoita, vain prosentti yli 40-vuotiaista osallistuu tutkintotavoitteiseen koulutukseen. Siksi henkilöstökoulutuksella on keskeinen sija ikääntyvien aikuisten ammattitaidon säilyttämisessä.
$\mathrm{H}$ pimisen) ja työn suhde on laajassa perspektiivissä muuttunut (Boud 2005). Oppiminen (koulutus) ja työ ovat olleet erottamattomia ennen modernia ajanjaksoa. Silloin elämistä, työn tekemistä ja oppimista ei eritelty, vaan ihmiset oppivat suoraan toisiltaan. Kun ammattikillat ja koulut kehittyivät, koulutus ja työelämä eriytyivät. Myöhäismodernina aikana on nähtävissä näiden kahden suhteen pirstaloituminen erityisesti peruskoulutuksen jälkeisissä koulutuksen muodoissa, sen sijaan peruskoulutuksen vahva asema koulutuspohjan luojana seuraaville koulutusasteille on säilynyt, mikä on pääteltävissä myös kansainvälisistä PISA -koulusaavutustutkimuksista (Kupari \& Välijärvi 2005). Vaikka jälkimodernissa yhteiskunnassa työn ja oppimisen suhde näyttää pirstaleiselta, on myös käynnissä työn ja oppimisen välinen uusintegraatio. Tämän prosessin seurauksena oppiminen on muuttunut työksi, ja vastaavasti työ jatkuvaksi uuden oppimiseksi. Se tosiasia, että tieto ja taidot hankitaan formaalin koulutuksen ulkopuolella, on tullut myös keskeiseksi kansalliseksi ja kansainväliseksi tutkimusteemaksi (ks. Billett, 2001; Fuller \& Unwin, 1998; Griffiths \& Guile, 2004; Lave \& Wenger, 1991, Järvinen \& Poikela 2001; Stenström 2008; Tynjälä 2008).

Koulutuksen ja työelämän suhdetta voidaan tarkastella (taulukko 1) edellä mainitun modernin kehityksen lisäksi taitoyhteiskunnasta tietoyhteiskuntaan siirtymisen vaiheena, jossa tietotyöläisten osuuden lisääntyminen on keskeistä (Nyhan 2002). Tässä yhteydessä tietotyöläisen tietoa ei nähdä pelkästään teoreettisena tietona, vaan erilaisen ymmärryksen integraationa ns. taitotietona (asiantuntemuksena). Tietoperustaisen yhteiskunnan syntyminen ei merkitse sitä, etteikö vanhassa taitoperustaisessa yhteiskunnassa olisi myös tietosisältöä. Lisäksi rajat eri vaiheiden välillä ovat huomaamattomia, nyky-yhteiskunnan eri alueilla esiintyy sekä modernin että taito- ja tietoyhteiskunnan eri vaiheita. Nykypäivän yhteiskuntaa on luonnehdittu tietoyhteiskunnan ohella myös oppimis- ja verkostoyhteiskunnaksi.

Koulutuksen vanhat tehtävät työvoiman kvalifioijina, sosiaalistajana ja valikoivana instituutiona ovat kohdanneet uusia haasteita myöhäismodernissa maailmassa. Koulutuksen tehtävänä on perinteisesti ollut valmistaa opiskelijat työmarkkinoille, tuottaa heille työelämässä tarvittavat kvalifikaatiot, pyrkiä takaamaan myös jatko-opintomahdollisuudet sekä kasvattaa ammattiin ja antaa taitoja elämässä selviytymiseen (Stenström 1997).

Koulu on erikoistunut opetukseen ja kasvatukseen. Työelämän tehtävänä on tuottaa tavaroita, palveluja ja ei-materiaalisia tuotteita. Oppilaitok- 
Taulukko 1. Koulutuksen ja työelämän suhde eri aikakausina (ks. Boud 2005; Nyhan 2002)

\begin{tabular}{|c|l|l|}
\hline Varhaismoderni yhteiskunta & Moderni yhteiskunta & Myöhäismoderni yhteiskunta \\
integroitunut & eriytynyt & $\begin{array}{l}\text { fragmentoitunut (sekä eriytynyt } \\
\text { että uusintegroitunut) }\end{array}$ \\
\hline $\begin{array}{c}\text { 'Vainottaa } \\
\text { 'kykyä tehdä' }\end{array}$ & $\begin{array}{l}\text { 'Yhteiskunta muutoksessa' } \\
\text { (kompetenssiperustainen) } \\
\text { painottaa } \\
\text { 'laajaa kompentenssia' }\end{array}$ & $\begin{array}{l}\text { 'Uusi (tieto)yhteiskunta' } \\
\text { painottaa } \\
\text { 'formaalin ja informaalin koulu- } \\
\text { tuksen integraatiota' } \\
\text { Tieto ja taitotieto }\end{array}$ \\
\hline 'Taitava työntekijä' & 'Pätevä työntekijä' & 'Tietotyöläinen' \\
\hline
\end{tabular}

sen toimintamallit ja kulttuuri ovat poikenneet työelämän toimintamalleista ja kulttuurista monessa suhteessa. Ammattiin valmistavan koulutuksen tehtävien yhteensovittamisen haasteena on ollut, miten valmistaa opiskelijoita jättämään taakseen koulutusjärjestelmä ja auttaa heitä pääsemään työelämään (tuotantoelämään) (Marhuenda 2000). Koulutuksen ja työelämän yhteistyö on oleellisesti lisääntynyt ja näiden molempien tehtävät ovat lähentyneet toisiaan. Miten tähän on tultu?

\section{Koulutuksen ja työelämän suhteiden tii- vistyminen}

Kansainväliset vertailut (mm. Stenström \& Lasonen, 2000) Suomen ja muiden Euroopan maiden ammatillisten koulutusjärjestelmien välillä ovat osoittaneet, että koulutuksen ja työelämän väliset yhteydet ovat olleet Suomessa vähäiset. Nyt tilanne on oleellisesti muuttunut. Suomalainen koulujärjestelmä on vastannut kansainvälistymisen (Bolognan ja Kööpenhaminan prosessit), globaalistumisen ja työelämän haasteisiin. Yli kymmenen vuotta sitten on perustettu korkeakoulusektorille ammattikorkeakoulut, joiden tarkoituksena on ollut kohottaa väestön koulutustasoa ja vastata työelämän alueellisiin haasteisiin (Salminen 2001; Stenström 2003; Virolainen, Vuorinen, Stenström \& Valkonen 2008).

Lisäksi koulutuksen ja työelämän väliset yhteydet ovat tiivistyneet viime aikoina ja tulleet osaksi opetussuunnitelmaa. Toisen asteen ammatillisessa koulutuksessa on otettu käyttöön kuuden kuukauden työssäoppimisen jakso, jossa opettajan ohella opiskelijan ohjaajana toimii työpaikkaohjaaja. Kokemukset työssäoppimisjaksoista ovat olleet myönteisiä (Lasonen 2001; Oulujärvi \& PeräRouhu 2000; Tynjälä, Virtanen \& Valkonen 2005; Tynjälä, Nikkanen, Volanen \& Valkonen 2005).

Koulutuksen ja työelämän yhteistyö on edelleen tiivistynyt toisen asteen ammatillisessa koulutuksessa, kun ammattiosaamisen näytöt on liitetty syksyllä 2006 ammatillisen peruskoulutuksen opetussuunnitelmaperusteiseen koulutukseen. Suomalaiseen ammatilliseen perustutkintoon kuuluvat näytöt edustavat uudenlaista järjestelmää, jossa yhdistyvät koulu- ja työelämälähtöisen ammatillisen koulutuksen elementit ja jossa näytöt nähdään ammattiin oppimisen prosessina. Ammattiosaamisen näytöt ovat tiivistäneet oppilaitosten työelämäyhteyksiä, lisänneet työelämälähtöisyyttä ja käytännön läheisyyttä parantamalla myös opiskelijoiden motivaatiota (Nyyssölä 2003b; Stenström 2005; Stenström, Laine \& Kurvonen 2006).

Vaikka kokemukset koulutuksen ja työelämän välisistä suhteista ovat myönteisiä, niin niissä on edelleen kehittämistä, jos tarkastelemme niitä ns. työkokemuksesta oppimisen mallien perusteella. Näistä konnektiivisen mallin piirteitä (Griffiths \& Guile 2004; Guile \& Griffiths 2001), jotka huomioivat teorian ja käytännön integraation, on havaittavissa ainoastaan harvoilla aloilla (Tynjälä, Virtanen \& Valkonen 2005; Virolainen 2006). Työssä oppimisen kokemusten hyödyntäminen sekä ammatillisessa että korkeakoulutuksessa kohtaavat samantyyppisiä haasteita. Näitä ovat esimerkiksi pedagogisten ja arvioinnin käytäntöjen kehittäminen sekä laadun takaaminen, sillä työssä oppimisen ympäristöt, opettajien työkokemus- ja arviointikäytännöt sekä työpaikkaohjaajien koulutus- ja arviointikokemukset vaihtelevat (Boud \& Solomon, 2001; Griffiths \& Guile, 2004; Guile \& Griffiths, 2001; 
Stenström \& Laine 2006; Stenström, Laine \& Kurvonen 2006; Stenström \& Tynjälä 2008; Tynjälä, Virtanen \& Valkonen 2005.)

\section{Ammattitaito koulutuksen ja työelämän rajapinnalla}

Keskeisimpiä koulutuksen ja työelämän rajapinnoilla olevia käsitteitä ovat ammattitaito, osaaminen, asiantuntijuus ja ammatillinen identiteetti. Tässä yhteydessä käsitellään ainoastaan ammattitaito -käsitettä. Työelämän nopeat muutokset ja niiden ennustamattomuus asettavat haasteita ammattitaidon määrittelylle ja sen kehittymiselle. Ammattitaidon käsite muuttuu jatkuvasti uusien työn kohteiden, muuttuvan työnjaon ja organisoinnin, teknologian ja uuden tiedon mukana (Kankaanpää 1997, 21; Otala 1992, 29; Stenström 2001).

Ammattitaito ei ole staattinen ominaisuus, vaan dynaaminen ja jatkuvasti muuttuva. Se muodostuu työprosessin sisäisistä suhteista, joihin liittyy aina myös muutospaineita aiheuttavia ristiriitoja ja jännitteitä. Nämä ristiriidat muodostuvat todellisen työprosessin ja todellisen ammattitaidon yhteensopivuusongelmista. (Kankaanpää 1997, 21; Ruoholinna 2000, 15; Stenström 2001, 28.)

Ammattitaidolla on monimutkainen suhde työpaikkojen ja työtehtävien lisäksi myös laajempaan kontekstiin: työmarkkinoihin. Ammattitaito, kompetenssi sekä kvalifikaatio voidaan nähdä saman käsiteperheen jäseninä. Niillä on yhteinen sisältöydin. Käsitteiden sisällöt eroavat toisistaan eri näkökulmien - työmarkkinoiden, työpaikkojen ja yksilön - mukaan. Per-Erik Ellström (2001) määrittelee osaamisen kompetenssin ja kvalifikaatioiden suhteen sekä tarkastelee sitä kolmesta erilaisesta näkökulmasta päätyen viiteen erilaiseen ammatillisen osaamisen merkitykseen.

Ensimmäinen näkökulma painottaa ammatillista osaamista yksilön ominaisuutena ja pääomana, joka sisältää sekä formaalin että todellisen osaamisen. Formaalilla tarkoitetaan koulutuksellista tai tutkinnon tuomaa osaamista. Todellinen osaaminen puolestaan sisältää yksilön potentiaalisen kapasiteetin suoriutua tehtävistä ja toimia erilaisissa tilanteissa. Toisen näkökulman mukaan ammatillinen osaaminen määritellään työn vaatimuksina, jotka voivat olla virallisia tai perustua todelliseen työssä vaadittavaan osaamiseen. Virallinen ja todellinen kompetenssi voivat poiketa toisistaan, sen sijaan ideaalitilanteessa ne kohtaavat toisensa. Kolmas näkökulma korostaa yksilön ja työn vuorovaikutusta ja työssä käytössä olevaa osaamista. Ammatillinen osaaminen ei ole yksilöön tai työhön liittyvä ominaisuus, vaan se liittyy molempiin sekä yksilöön että työhön. (Paloniemi 2004, 21; Ruohotie 2002; Stenström, Laine \& Valkonen 2005).

\section{Ammattitaidon haasteet}

Koulutuksen liittäminen ammattitaitoon johtaa määrittelyyn, että ammattitaito on koulutuksella ja kokemuksella hankittu pätevyys toimia määrätyssä ammatissa. Ammattitaito opitaan erilaisissa konteksteissa. Useat viimeaikaiset tutkimukset kuitenkin osoittavat, että ammattilaiset kokevat oppineensa jopa suurimman osa työssä tarvittavista taidoista vasta työssä (Collin 2005; Stenström 2006; Tynjälä ym. 2006). Koulutuksen tutkimuslaitoksella on selvitetty ammattikorkeakoulusta valmistuneiden sijoittumista työelämään 1990-luvulta lähtien (Korhonen, Mäkinen \& Valkonen 1999; 2000; 2001; Virolainen \& Valkonen 2002; Stenström 2003). Tulosten perusteella (Stenström, Laine \& Valkonen 2005; Vuorinen \& Valkonen 2007; Virolainen, Vuorinen, Stenström \& Valkonen 2008) valmistuneet ovat työllistyneet hyvin, mutta se on vasta osa totuutta. Valmistuneet kokevat, etteivät he ole saaneet riittävästi työelämässä tarvittavia

Kuvio 1. Ammattitaidon erilaiset määritelmät (Ellström 2001)

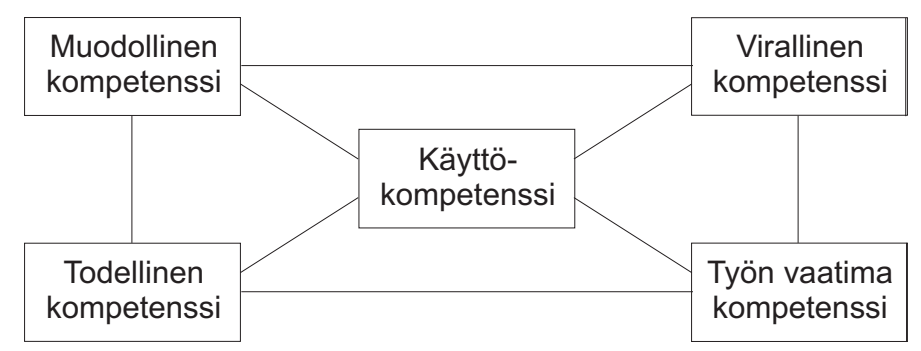


asiantuntijavalmiuksia, joista tosin osa saavutetaan vasta kokemuksen kautta. Opiskelijoiden työelämävalmiuksien kehittäminen asettaa haasteita ammattikorkeakouluille, joiden tavoitteissa kiinnitetään huomio työ- ja elinkeinoelämän vaatimuksiin. Tässä tarvitaan koulutuksen ja työelämän sekä eri koulutustasojen välistä vuoropuhelua. Keskeisessä roolissa yhteistyön rakentamisessa ovat erilaiset toimijat: koulutuksen (opettajat, opiskelijat) ja työelämän edustajat (työntekijät, työnantajat). Nyt kun ammattikorkeakoulut ovat kehittäneet järjestelmäänsä ja vakiinnuttaneet asemansa suomalaisessa korkeakoulutuksessa, on erityisesti pedagogisen kehittämisen aika (ks. myös Vuorinen \& Valkonen 2007).

Työelämän muutos nostaa esiin uudenlaisen osaamisen ja perustaitojen tarpeen. Työelämässä on ollut aina täynnä epävarmuutta, mutta nykyinen epävarmuus poikkeaa aiemmasta. Kun ammatit muuttuvat ja murenevat, mitä jää jäljelle? Ammattilaiselta vaaditaan aina ajantasaisia ammattispesifisiä taitoja ja tietoja, mutta yhä keskeisemmäksi ovat tulleet avaintaidot, joita kuvataan työntekijän työtehtävästä toiseen siirtymisen taidoiksi. Avaintaidoista käytetään monenlaisia nimityksiä, puhutaan myös yliammatillisista taidoista. Euroopan Unioni (2006) on listannut kahdeksan avaintaitoa, joiden tarkoituksena on helpottaa EUkansalaisten sopeutumista tietoyhteiskunnan muutoksiin. Näitä avaintaitoja ovat mm. kielitaito, matematiikan ja luonnontieteiden osaaminen, tietotekniset, oppimis-, sosiaaliset ja kansalaistaidot, sekä aloitekyky ja yrittäjyys. Avaintaidot ovat eurooppalaisessa kontekstissa yksi keskeinen keskustelun ja tutkimuksen kohde. Erityisesti sosiaalisten vuorovaikutus- ja kommunikointitaitojen merkitys on kasvanut ryhmä-, tiimi- ja projektiluonteisten työmuotojen yleistettyä (Tikkamäki 2006).

On ennakoitu, että tietoyhteiskunnan vaatimusten myötä työtehtävät eriytyvät yli 45-vuotiaiden ja nuorempien kesken eri tavoin. Nuoremmat hakeutuvat tietoteknisiin töihin sekä palveluammatteihin, kun taas ikääntyvät jäävät perinteisemmille ammattialoille. Kyse ei ole vain välineellisten ja teknisten taitojen hallinnasta (Ilmarinen 1999, 40). Tietotekniset taidot ovat osoittautuneet keskeisiksi aikuisten koulutushalukkuutta ja syrjäytymiskehitystä ehkäiseväksi tekijäksi (Stenström, Linnakylä, Malin, Nikkanen, Piesanen \& Valkonen 2002). Aikuisväestön erilaisten koulutusmuotojen kehittäminen tulisikin olla osa elinikäisen oppimisen strategiaa.

\section{Elinikäinen oppiminen avain- prosessinamuutoksessa}

Elinikäinen oppiminen voidaan nähdä erääksi avainprosessiksi muutoksen hallinnassa. Elinikäisen oppimisen merkitys jälkimodernissa yhteiskunnassa on korostunut ja sen edistäminen on nähty keskeisenä välineenä (ikääntyvän) väestön työllistyvyyden parantamisessa ja ylläpitämisessä sekä ammatillisen liikkuvuuden lisääntymisessä. Kansainvälisesti tarkasteltuna suomalaiset ovat aktiivisia aikuisopiskelijoita. Kun tilannetta tarkastellaan iän ja koulutustavoitteen mukaan, niin ainoastaan yksi prosentti yli 40-vuotiaista osallistui tutkintotavoitteiseen koulutukseen (Linnäkylä \& Malin 2002). Siksi henkilöstökoulutuksella on keskeinen sija ikääntyvien aikuisten ammattitaidon säilyttämisessä (Stenström 2002). Eurooppalaisten tilastojen mukaan vuonna 2009 ennustetaan työmarkkinoilla olevan vähemmän 15-24 -vuotiaita kuin 55-66 - vuotiaita (Lipinska, Schmid \& Tessaring 2007).

Elinikäisen oppimisen vaatimuksen myötä yksilön valintojen niin koulutuksessa kuin työelämässä oletetaan moninaistuvan ja lisääntyvän (Baptiste 1999; Hake 1999). Baumanin (2002, 199) mukaan kukaan järkevä henkilö ei enää odota viettävänsä koko työikäänsä, tai suurta osaa siitä, yhden ja saman yhtiön palveluksessa. Tällöin tärkeiksi tulevat yksilöiden taidot suorittaa valintoja ja korjata epäonnistuneita valintoja, samalla kun ohjauksen tarve yksilön eri elämänvaiheissa korostuu.

Entisaikojen tapaan elinikäisen oppimisen ajatuksen taustalla ei ole pelkästään humanistinen ihanne yksilöstä itsensä sivistäjänä. Pikemminkin tilalle on tullut osaamisen pakko menestyä työssä ja elämässä (Tight 1999). Mikäli työelämän perusrakenteiden muuttuessa yksittäinen työntekijä ei ole valmis täydentämään omaa peruskoulutustaan, syrjäytymisen riski työelämästä muodostuu yhä todennäköisemmäksi (Laukkanen 2000, 270; Stenström ym. 2002).

\section{Koulutuksen ja työelämän kehittäminen}

Menestyvän talouden keskeisenä moottorina nähdään korkeatasoinen koulutus. Lissabonin strategian mukaan Euroopan tarkoituksena on pyrkiä kilpailukykyisimmäksi ja dynaamisimmaksi tietoperustaiseksi taloudeksi maailmassa. Tällöin eu- 
rooppalaisten koulutusjärjestelmien oletetaan sopeutuvan tietoyhteiskunnan vaatimuksiin ja ennakoivan muuttuvien taitojen tarpeen. Globalisaatio, teknologiset ja demografiset muutokset (sisältäen ikääntymisen ja muuttoliikkeen) asettavat suuria haasteita. Eurooppa on kokenut jatkuvan muutoksen erityisesti maataloudesta ja perinteisestä teollisuudesta kohti palvelu- ja tietoyhteiskuntaa. Näiden trendien oletetaan myös jatkuvan ja polarisaation etenevän. (Cedefop 2008.)

Myös suomalaisen teollisuuden sisäinen rakenne on nopeasti muuttunut viimeisen kahdenkymmenen vuoden aikana. Korkean teknologian teollisuuden ja palveluammattien suhteellinen osuus on lisääntynyt. Tämä näkyy myös ammatilliseen koulutukseen hakeutumisessa vuonna 2008, sillä eniten kasvoi tekniikan ja liikenteen alalle hakijoiden osuus. Lisäksi yli puolet ikäluokasta pyrki tänä keväänä ammatilliseen koulutukseen (Opetushallitus 2008), jonka vetovoima on selvästi lisääntynyt. Syitä tähän voidaan etsiä suomalaisen ammatillisen peruskoulutuksen erityispiirteistä, joita ovat ammatillisen koulutuksen asema korkea-asteen opintoihin valmistavana väylänä ja työssäoppimisen rooli osana formaalia koulutusta (ks. Virolainen 2002). Työpaikalla tapahtuvan oppimisen sisältyminen formaaliin koulutukseen on tuonut suomalaiseen koulujärjestelmään kaivatun työelämäyhteyden, jossa haasteita ja kehittämisen kohteita riittää jatkossakin.

Ammatilliset oppilaitokset ja korkeakoulut nähdään yhä enemmän tärkeänä osana innovaatiojärjestelmää ja alueellista kehittämistä. Koulutuksen ja työelämän haasteisiin vastaaminen edellyttää tutkimus- ja kehittämistoiminnalta siis teorian ja käytännön jatkuvaa dialogia, monitieteistä lähestymistapaa sekä paikallista, kansallista ja kansainvälistä yhteistyötä myös akateemisella kentällä.

\section{Lähteet}

Baptiste, I. (1999). Beyond lifelong learning. A call to civically responsible change. International Journal of Lifelong Education, 18 (2), 94-102.

Bauman, Z. (2002). Notkea moderni. Tampere: Vastapaino.

Billet, S. (2001). Knowing in practice: Re-conceptualising vocational expertise. Learning and Instruction, 11(1), 431-452.

Boud, D. (2005). Work and learning: some challenges for practice. Teoksessa E. Poikela (toim.) Osaaminen ja kokemus. Tampere:

Tampereen yliopistopaino, 181-199.

Boud, D., \& Salomon, N. (2001). Repositioning universities and work. In D. Boud \& N. Salomon (Eds.), Work-based learning. A new higher education? Buckingham, England: Society for Research into Higher Education \& Open University Press, 18-33.

Cedefop. (2008). Future skill needs in Europe. Meriun-term forcast. Synthesis repot. Luxembourg: Office for Official Publications of the European Communities.

Collin, K. (2005). Experience and shared practice design engineers' learning at work. Jyväskylä Studies in Education, Psychology and Social Research 261.

Ellström, P.-E. (2001). The many meanings of occupational competence and qualification. In W. Nijhof \& J. Streumer (Eds.) Key qualifications in work and education. Dordrect: Kluwer Academic Publishers, 39-50.

Fuller, A., \& Unwin. L. (1998) Reconceptualizing apprenticeship: Exploring the relationships between work and learning. Journal of Vocational Education and Training, 50(2), 153-172.

Griffiths, T., \& Guile, D. (2004). Learning through work experience for the knowledge economy. Issues for educational research and policy. (CEDEFOP Reference series No. 48). Luxembourg: Office for Official Publications of the European Communities.

Guile, D., \& Griffiths, T. (2001). Learning through work experience. Journal of Education and Work, 14(1), 113-131.

Hake, B. J. (1999). Lifelong learning in late modernity: The challenges to society, organizations, and individuals. Adult Education Quarterly 49 (2), 79-90.

Ilmarinen, J. (1999). Suomalaiset ikääntyvät. Teoksessa Työ vuonna 2005. Näkymiä suomalaiseen työelämään. Helsinki: Työterveyslaitos, 38-46.

Järvinen, A. \& Poikela, E. (2001). Modelling reflective and contextual learning at work. Journal of Workplace Learning 13 (7/8), 282-289.

Kankaanpää, A. (1997). Ammatin kuvaus koulutuksen apuna. Ammattien kuvausjärjestelmän rakentamisen näkökulmia, ongelmia ja ehdotuksia. Helsinki: Opetushallitus. 
Korhonen, K., Mäkinen, R. \& Valkonen, S. (1999). Kaupallisen korkea-asteen tutkinnolla työelämään. Jyväskylän yliopisto. Koulutuksen tutkimuslaitos. Tutkimusselosteita 5.

Korhonen, K., Mäkinen, R. \& Valkonen, S. (2000). Insinöörin tutkinnolla työelämään. Jyväskylän yliopisto. Koulutuksen tutkimuslaitos. Tutkimusselosteita 9.

Korhonen, K., Mäkinen, R. \& Valkonen, S. (2001). Sosiaali- ja terveysalan tutkinnolla työelämään. Jyväskylän yliopisto. Koulutuksen tutkimuslaitos. Tutkimusselosteita 13.

Kupari, P. \& Välijärvi, J. (2005). Osaaminen kestävällä pohjalla. PISA 2003 Suomessa. Jyväskylän yliopisto, Koulutuksen tutkimuslaitos.

Lasonen, J. (2001). Työpaikat oppimisympäristöinä: työpaikkajohtajien, opiskelijoiden, työpaikkaohjaajien ja opettajien arviot Silta-hankkeen $(2+1)$ kokeilun kokemuksista. Helsinki: Opetushallitus.

Laukkanen, R. (2000). Aikuiskasvatus tukee elämänhallintaa. Aikuiskasvatus, 20 (3), 269-270.

Lave, J., \& Wenger, E. (1991). Situated learning: Legitimate peripheral participation. Cambridge: Cambridge University Press.

Linnakylä, P. \& Malin, A. (2002). Yli 40-vuotiaat aikuiskoulutuksessa: Aikuiskoulutukseen osallistuminen ja siitä syrjäytyminen SIALSaineiston valossa. Teoksessa M.-L. Stenström, P. Linnakylä, A. Malin, P. Nikkanen, E. Piesanen \& S. Valkonen. Yli 40-vuotiaat aikuiskoulutuksessa. "Kyllä sieltä aina jotain reppuun jää”. Opetusministeriö, 171-236.

Lipinska, P., Schmid, E. \& Tessaring, M. (2007). Zooming in on 2010. Reassessing vocational education and training. Luxembourg: Office for Official Publications of the European Communities.

Marhuenda, F. (2000). Rethinking educationwork relationships. In M-L. Stenström \& J. Lasonen (eds.) Strategies for reforming initial vocational education in Europe. Jyväskylä: Institute for Educational Research, University of Jyväskylä, 239-249.

Nyhan, B. (2002). Knowledge development, research and collaborative learning. In B. Nyhan (Ed.) Taking steps towards the knowledge society. Reflections on the process of knowledge development. Cedefop Reference series 35.
Luxembourg: Office for Official Publications of the European Communities, 18-38.

Nyyssölä, N. (2003). Näytöt ammatillisessa peruskoulutuksessa 2002. Väliraportti näyttöprojektien toiminnasta. Opetushallitus.

Opetushallitus (2008). Yli 90000 haki yhteishaussa. Viitattu 2.5.2008. http://www.oph.fi/ page.asp?path=1,434,84377

Otala, L. (1992). Koulutus menestystekijänä. Suomen itsenäisyyden juhlarahasto. Sitra 122.

Oulujärvi, J. \& Perä-Rouhu, E. (2000). Oppiminen työelämässä - työssäoppiminen opiskelussa. Koulutuksen ja työelämän yhteistyötä Leonardo da Vinci -projekteissa. Helsinki: Opetushallitus.

Paloniemi, S. (2004). Ikä, kokemus ja osaaminen: työntekijöiden käsityksiä iän ja kokemuksen merkityksestä ammatillisessa osaamisessa ja sen kehittämisessä. Jyväskylä Studies in Education, Psychology and Social Research. 253.

Ruoholinna, T. (2000). Koulutus vai kokemus? Työtaitojen oppiminen opetuksen ja kaupan aloilla. Turun yliopisto. Kasvatustieteiden tiedekunta. Julkaisusarja A, 192.

Ruohotie, P. (2002). Kvalifikaatioiden ja kompetenssien kehittäminen ammattikorkeakoulun tavoitteena. Teoksessa J-P. Liljander (toim.) Omalla tiellä. Ammattikorkeakoulut kymmenen vuotta. Helsinki: Edita, 108-127.

Salminen, H. (2001). Suomalainen ammattikorkeakoulu-uudistus opetushallinnon prosessina. Koulutussuunnittelu valtion keskushallinnon näkökulmasta. Opetusministeriö. Koulutus- ja tiedepolitiikan osasto. Julkaisusarja 81.

Stenström, M-L. (1997). Educational and gender equality in vocational education. The case of commercial education in Finland. Institute for Educational Research. University of Jyväskylä. Research Reports 1 .

Stenström, M.-L. 2002. Aikuiset koulutuksessa: Yhteenvetoa ja johtopäätöksiä 40+ -tutkimuksesta. Teoksessa M-L. Stenström, P. Linnakylä, A. Malin, P. Nikkanen, E. Piesanen \& S. Valkonen. 2002. Yli 40-vuotiaat aikuiskoulutuksessa: 'Kyllä sieltä aina jotakin reppuun jää!’ Helsinki: Opetusministeriö, 237-245.

Stenström, M.-L. 2003. Transition from polytechnics to working life in Finland. European Journal for Vocational Training, 28, 65- 72. 
Stenström, M.-L. (2006). Polytechnic graduates’ working life skills and expertise. In P. Tynjälä, J. Välimaa \& G. Boulton-Lewis (Eds.) Higher education and working life collaborations, confrontations and challenges. Advances in learning and instruction book series. Pergamon \& EARLI, Amsterdam: Elsevier, 89-102.

Stenström, M.-L. (2008). Connecting work and learning through demonstrations of vocational skills: Experiences from the Finnish VET. In M.-L. Stenström \& P. Tynjälä (Eds.). Towards integration of work and learning. Strategies for connectivity and transformation. Dordrecht: Springer (in print).

Stenström, M-L. \& Laine, K. (toim.). (2006). Quality and practice in assessment: New approaches in work-related learning. University of Jyväskylä. Institute for Educational Research.

Stenström, M-L., Laine, K. \& Kurvonen, L. (2006). Practice-oriented assessment in Finnish VET Towards quality assurance through vocational skills demonstrations. Teoksessa M-L. Stenström \& K. Laine (toim.). Quality and practice in assessment: New approaches in work-related learning. University of Jyväskylä. Institute for Educational Research, 89-120.

Stenström, M-L., Laine, K. \& Valkonen, S. (2005). Ammattikorkeakoulut väylänä työelämään. Hallinnon ja kaupan, tekniikan ja liikenteen sekä sosiaali- ja terveysaloilta valmistuneiden työelämään sijoittuminen ja työelämätaidot. Tutkimusselosteita 21. Jyväskylä: Jyväskylän yliopisto, Koulutuksen tutkimuslaitos.

Stenström, M.-L., Linnakylä, P., Malin, A., Nikkanen, P., Piesanen, E. \& Valkonen, S. (2002). Yli 40-vuotiaat aikuiskoulutuksessa: 'Kyllä sieltä aina jotakin reppuun jää!’ Opetusministeriö.

Stenström, M.-L. \& Tynjälä, P. (Eds.) (2008). Towards integration of work and learning. Strategies for connectivity and transformation. Dordrecht: Springer (in print).

Tight, M. 1999. Mythologies of adult/continuing/lifelong education. Paper presented at SCUTREA, 29 ${ }^{\text {th }}$ Annual Conference, 5-7 July, University of Warwirk, England. (Available: http://www.leeds.ac.uk/educol/documents/ 000001021.htm)

Tikkamäki, K. (2006). Työn ja organisaation muutoksissa oppiminen: etnografinen löytöretki työn oppimiseen. Tampere University Press.
Tynjälä, P. (2008). Connectivity and transformation in work-related learning - theoretical foundations. In M.-L. Stenström \& P. Tynjälä (Eds.). Towards integration of work and learning. Strategies for connectivity and transformation. Dordrecht: Springer (in print).

Tynjälä, P., Slotte, V., Nieminen, J., Lonka, K., \& Olkinuora, E. (2006). From university to working life: Graduates’ workplace skills in practice. In P. Tynjälä, J. Välimaa, \& G. Boulton-Lewis (Eds.) Higher education and working life: Collaborations, confrontations and challenges. Amsterdam: Elsevier, 77-88.

Tynjälä, P., Virtanen, A. \& Valkonen, S. (2005). Työssäoppiminen Keski-Suomessa. Taitava Keski-Suomi -tutkimus. Osa I. Jyväskylän yliopisto. Koulutuksen tutkimuslaitos. Tutkimusselosteita 23.

Virolainen, M. (2006). Osaamista rakentamassa: Ammattikorkeakoulut harjoittelujen ja työelämäyhteistyön kehittäjänä. Jyväskylän yliopisto. Koulutuksen tutkimuslaitos. Tutkimusselosteita 27.

Virolainen, M. \& Valkonen, S. (2002). Ammattikorkeakouluista ja yliopistoista työelämään. Jyväskylän yliopisto. Koulutuksen tutkimuslaitos. Tutkimusselosteita 16

Virolainen, M., Vuorinen, P., Stenström, M.-L. \& Valkonen, S. (2008). Riittääkö hyvä työllistyminen ammattikorkeakoulujen tavoitteeksi? Tiedepolitiikka, 33 (1), 17-24.

Vuorinen, P. \& Valkonen, S. (2008). Korkeakoulutuksesta työelämään. Jyväskylän yliopisto. Koulutuksen tutkimuslaitos. Tutkimusselosteita 37.

Professori Marja-Leena Stenströmin virkaanastujaispuhe, jonka hän piti Jyväskylän yliopistossa 7. toukokuuta 2008. Stenströmin professuuri alkoi 1. maaliskuuta. ja sen sijoittuu koulutuksen tutkimuslaitokseen KTL:ään.

Marja-Leena Stenströmin tehtävänä on edistää koulutuksen ja työelämän suhteita koskevaa tutkimusta painopisteenä koulutusjärjestelmän kehittymisen ja koulutuksen vaikuttavuuden tutkimus.

Stenströmin viimeaikainen tutkimus on keskittynyt ammatilliseen koulutukseen ja osaamiseen, koulutuksen ja työelämän väliseen suhteeseen sekä siirtymiseen ammattikorkea-koulusta työelämään. Hän on johtanut useita kansallisia ja kansainvälisiä tutkimusprojekteja sekä osallistunut aktiivisesti asiantuntijatehtäviin.

Kuva: Tarja Vänskä-Kauhanen 